\title{
Effect of Parvovirus B19 in Diabetes Mellitus Type 1
}

\author{
Ahmed Hasan Mohammed ${ }^{1 *}$ and Alzahraa Albatool Ibrahim saber ${ }^{2}$ \\ (ahmedhasan5@sci.utq.edu.iq ${ }^{1}$, alzahraan25@yahoo.com²) \\ ${ }^{1}$ University of Thi-Qar, College of Science, Pathological Analysis Department, Nasiriyah, Iraq \\ ${ }^{2}$ Higher Health Institution, Thi-Qar Health Directorate, Nasiriyah, Iraq
}

\begin{abstract}
Type 1 diabetes mellitus (T1D) is one of the complicated diseases and many studies indicated the contribution of viruses in the consequences of T1D. The present study aimed to detect of Parvovirus B19 NS1 gene in the sera of T1D patients by using conventional PCR. Forty-five patients with T1D have been conducted in this study based on clinical examination and laboratory evaluation of random blood sugar, fasting blood sugar, and glycated hemoglobin. Viral genome extraction was made according to the kit manufacture's manual then conventional PCR and gel electrophoresis was performed to detect the target genome. The results showed the presence of NS 1 gene in 7 (14\%) of 45 patients included in this study, so conclude that the detection of viral genome in the blood samples of T1D patients is not sufficient to prove that human Parvovirus B19 has a role in the pathogenesis and consequences of T1D.
\end{abstract}

Keywords: Parvovirus B19, type 1 diabetes mellitus, PCR, fasting blood sugar.

\section{Introduction}

Type 1 diabetes (T1D) is an autoimmune disorder that usually strikes individuals at almost any age. It is caused by autoreactive T cells [1]. The 2019 International Diabetes Federation (IDF) states that T1D incidence, prevalence, and mortality estimates for children $<15$ years for all 211 countries. The estimated cases were about 600,900 and incident cases around 98,200. So many countries were continuing to be affected and remain to have the highest rate and others have seen lowest rate as in East and South-East Asia. Generally speaking 3-4\% per year there is an increase of incidents for such type of illness. On top of that T1D mortality has drastically decreased, , especially in people with diabetic nephropathy [2].

It is known that genetic and environmental factors could affects the major contribution for the development of the disease. Viruses may consider the main onset of T1D [3]. It is found in some cases there is a link between T1D and viruses including DNA viruses from families Herpesviridae and Parvoviridae and RNA viruses of families Togaviridae, Paramyxoviridae, Retroviridae, and Picornaviridae. There is a strong relationship between T1D and enteroviruses [4]; wherever, there is the uncertainty of the relation of diabetes to enteroviruses [3]. Multi models applied in some cases to highlight the triggering to beta-cell pancreatic destruction however, there is no indication of introducing other viruses [5]. Parvovirus B19 (B19V), is a member of enteroviruses that belongs to the family Parvoviridae, genus Erythroparvovirus may have a role in the development of T1D. Several cases of autoimmune disease that occur after 
acute infection with $\mathrm{B} 19 \mathrm{~V}$ have been reported. Kasuga et al. reported an association between T1D and infection with parvovirus B19in young adults who showed serum levels of B19 IgM and antibodies to the diabetic autoantigen IA-2 were significantly elevated [6,7]. Whereas rat virus parvovirus Kilham showed autoimmune diabetes in rats [8] for which T1D had not clarified [6]. This work targeted the presence of B19V in T1D patients by detection of the B19V NS1 gene in the blood sample of T1D patients using conventional PCR.

\section{Patients and Method}

\subsection{Study Design}

A study was covered with 45 T1D patients attending the Special Center of the Endocrine Glands and Diabetes in Al-Nasiriyah city, south of Iraq. Known cases of T1D patients (males and females) of age range 3-16 years with their demographic or clinical information regarding age, sex, weight, the duration of the disease, insulin therapy (Number of doses during the day and type of insulin), family members with T1D and T2D and clinical history of the patients were mandatory for inclusion criteria.

\subsection{Sample Collection}

Five milliliters of venous whole blood were withdrawn by $5.0 \mathrm{ml}$ syringe sterile disposable. About $1.0 \mathrm{ml}$ was separated in the EDTA tube for the HbA1c test and the remaining ( $4.0 \mathrm{ml})$ of the blood samples was collected in a sterile gel tube, subsequently allowed to clot, and centrifuged at $3000 \mathrm{rpm}$ for $10 \mathrm{~min}$ for serum separation to perform the blood sugar tests and extraction of the viral genome.

\subsection{Blood Sugar Tests}

The blood sugar test was done by using the RANDOX kit/ UK. Glucose oxidase and hydrogen peroxide were considered and formed the basis for tests requirements.

\subsection{HbA1c Test}

It is a test to count 2 to 3 months' average blood sugar level. It is based on the principle of fluorescence immunoassay technology by using the Finecare HbA1C Rapid Quantitative test kit/China. The test uses a sandwich immunodetection method.

\subsection{Viral genome extraction and PCR}

The viral genomic DNA was considered from serum samples using the viral nucleic acid extraction kit from Qiagen/USA, according to the manufacturer's protocol. The conventional PCR technique has been used in this study for amplification of the NS1 gene of B19

$\mathrm{V}$ and the primers designed by (Alpha DNA/ Canada) include: (Forward primer 5'-GCC GCC AAG TAG AGG AA-3' and reverse primer 5'-CCA CGA TGC AGC TAC AA-3'). The PCR reaction mix consisted of $5 \mu \mathrm{l}$ of extracted DNA, $1 \mu \mathrm{l}$ of forward and reverse primers, and $13 \mu \mathrm{l}$ distilled water. All these components were placed in the PCR tubes that contents all other components and the final volume in the reaction tube was $20 \mu \mathrm{L}$. The extension for the PCR product was at $72{ }^{\circ} \mathrm{C}$ for $7 \mathrm{~min}$. The PCR was validated over $2 \%$ gel electrophoresis with Green Star ${ }^{\mathrm{TM}}$ Nucleic Acid Staining solution I upon preparation. 


\section{Results}

The present study included 45 patients having T1D with age range $3-16$ years old. Demographic data for those patients showed that the percentage of males among T1D patients was $(35.5 \%)$ and the percentage of females was $(64.5 \%)$. While the age and the bodyweight of all subjects representing by mean \pm SD are as follows, $(10.02 \pm 3.14)$ and $(31.85 \pm 11.73)$, respectively.

The biochemical test results of fasting blood sugar, random blood sugar, and HbA1c test for patients group represented by mean \pm SD were $(217.02 \pm 107.61),(328.87 \pm 117.92)$ and $(10.74$ \pm 3.43 ) respectively table $(1)$.

The results of the PCR technique detected the presence of the B19V NS1 gene in only 7 (14\%) of T1D patients, whereas the others $(86 \%)$ gave negative results (figure 1 ). This study evaluates the effect of the presence of B19V on clinical data which was measured for T1D patients, and the results showed there was no effect for the B19V on each of fasting blood sugar, random blood sugar, and glycated hemoglobin. On the other hand, the results also showed, and weight in the presence or absence of the B19V table (2).

Table 1. List of elements of diabetes mellitus type 1.

\begin{tabular}{|c|c|}
\hline Demographic or Clinical data & Percentage or Mean $( \pm$ SD) \\
\hline Sex & Male: $35.5 \%$ \\
& Female: $64.5 \%$ \\
\hline Age & $10.02 \pm 3.14$ \\
\hline Weight & $31.85 \pm 11.73$ \\
\hline FBS & $217.02 \pm 107.61$ \\
\hline RBS & $328.87 \pm 117.92$ \\
\hline HbA1c & $10.74 \pm 3.43$ \\
\hline
\end{tabular}

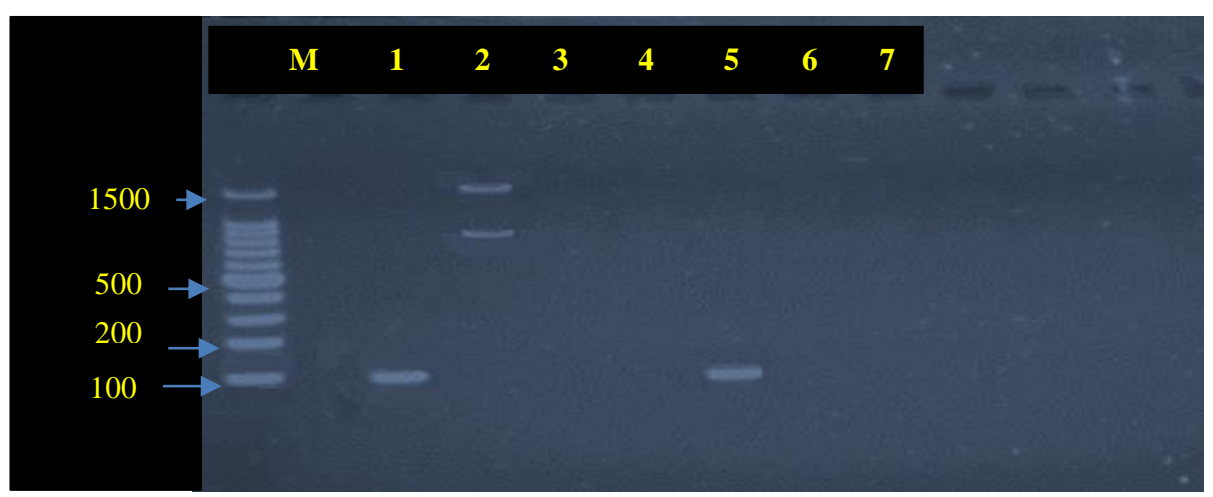

Fig 1. Detection of Parvovirus B9 (NS1) Gene by Conventional PCR. NS1Gene molecular position $120 \mathrm{bp}$, lines (2, and 6) in this image and other samples are negative. 
Table 2. Type 1 diabetes mellitus patients according to PCR results.

\begin{tabular}{|l|l|l|l|}
\hline \multirow{2}{*}{ Item } & PCR positive & PCR Negative & P-value \\
\cline { 2 - 3 } & Mean \pm SD & Mean \pm SD & \\
\hline Age & $10 \pm 2.1$ & $10 \pm 3.3$ & $\mathrm{P}=0.978$ \\
\hline Weight & $35 \pm 11.5$ & $31 \pm 11.8$ & $\mathrm{P}=0.452$ \\
\hline FBS & $194.5 \pm 100$ & $221 \pm 109.7$ & $\mathrm{P}=0.540$ \\
\hline RBS & $298 \pm 41.7$ & $334.5 \pm 126.6$ & $\mathrm{P}=0.168$ \\
\hline HbA1c & $10.5 \pm 2.4$ & $11 \pm 2.3$ & $\mathrm{P}=0.587$ \\
\hline
\end{tabular}

\section{Discussion}

For a long time, there are many studies have been suggested that viruses such as Coxsackie B, Rubella, Mumps, Cytomegalo viruses, Epstein Barr virus, Parvovirus B 19, Hepatitis C virus, Retrovirus, Rotavirus, and HIV appear to play a vital role among the numerous environmental factors, which together with the genetic susceptibility, may be implicated in the pathogenesis of T1D $[9,10,11,12,13]$.

The present study included some of the demographic parameters (such as sex, age, and body weight) and biochemical parameters (such as F.B.S, R.B.S, and HbA1c) to give a clear picture of the epidemiological and clinical situation of T1D patients, who included in this study. A large proportion of patients with T1D was females (64.5\%) compared with males (35.5\%). This result corresponds with the results of studies conducted in Australia, Oman, Saudi Arabia, Libya, and Egypt [14] but, it differs from other studies in Kuwait, Tunisia, and Basra city which showed that T1D was higher in males than females $[15,16]$.

Patients in this study were selected from the age of children and adolescents with a mean of $(10.02 \pm 3.14)$ for early detection of the virus would be easier and more possible than the patients if they were older. In addition, T1D is frequently diagnosed during childhood and adolescence [17]. The epidemiological trends reported the number of children and adolescents with T1D at school are continued to increase $[18,19]$. where the average global incidence rate increasing by $3 \%$ to $4 \%$ per annul [20]. Many countries have also reported that children are much younger at the time of diagnosis [21,22]. While another study showed an increase [23].

This study also included biochemical tests such as (F.B.S, R.B.S, and HbA1c). They are one of the basic tests approved by the World Health Organization (WHO) since they have an essential role in determining the management of diabetes mellitus. Also, a very young child does not always show clear symptoms [24,25]. The results of these tests in the present study showed significant elevation than the normal value because the patients with T1D have a disturbance in the pancreas, so a little or no insulin is released, resulting in glucose accumulation in the bloodstream and, as a result, an increase in glucose concentrations in diabetic patients [26]. The molecular diagnosis represented by the PCR assay of the current study showed the presence of the B19V NS1 gene in $7(14 \%)$ of T1D patients. Although this is a small percentage, it may show a potential relationship between B19V infection and T1D consequences [27-28]. However, we cannot assert an association between current or past B19V infection and the development of T1D in these patients and required further investigations. 
Acknowledgment: thanks should go to the Center of Diabetes and Endocrine Glands in AlNasiriyah city, Iraq for their collaboration during samples collection.

\section{References}

1. Giwa AM, Ahmed R, Omidian Z, Majety N, Karakus KE, Omer SM, et al. Current understandings of the pathogenesis of type 1 diabetes: Genetics to environment. World J Diabetes. 2020;11(1):1325.

2. Tuomilehto J, Ogle G, Lund-Blix N, Stene L. Update on Worldwide Trends in Occurrence of Childhood Type 1 Diabetes in 2020. Pediatr Endocrinol Rev. 2020;17: 198-209.

3. Report C, Sunumu O, Bir P, Diyabetik H, Fulminan A. Parvovirus Infection in a Child Complicated with Diabetic Ketoacidosis and Acute Fulminant Hepatitis: A Case Report. 2017;11(2):92-4.

4. Yeung W-CG, Rawlinson WD, Craig ME. Enterovirus infection and type 1 diabetes mellitus: systematic review and meta-analysis of observational molecular studies. BMJ. 2011; 342.

5. Wamsingh A, Chapman N, Tracy S. Coxsackieviruses and diabetes. Bioessays, 1997; 19(9): 793-800.

6. O’Bryan TA, Beck MJ, Demers LM, Naides SJ. Human parvovirus B19 infection in children with new onset Type 1 diabetes mellitus. Diabet Med. 2005;22(12):1778-1779.

7. Kasuga A, Harada R, Saruta T. Insulin-dependent diabetes mellitus associated with parvovirus B19 infection. Ann Intern Med. 1996;125(8): 700-701.

8. Ellerman KE, Richards CA, Guberski DL, Shek W, An L. Kilham Rat Virus Triggers T-CellDependent Autoimmune Diabetes in Multiple Strains of Rat. Diabetes. 1996;45(5): 557-562.

9. Blomqvist M, Juhela S, Erkkila S, Korhonen S, Simell T, Kupila A, et al. Rotavirus infections and development of diabetes-associated autoantibodies during the first 2 years of life. Clin Exp Immunol. 2002;128(3): 511-515.

10. Christen U, Herrath M. Infections and Autoimmunity--Good or Bad? J Immunol. 2005; 174(12): 7481-7486.

11. Fujinami R, Herrath M, Christen U, Whitton J. Molecular Mimicry, Bystander Activation, or Viral Persistence: Infections and Autoimmune Disease. Clin Microbiol Rev. 2006; 19(1): 80-94.

12. Saber AZABI, Mohammed AH. The roles of human cytomegalovirus and Epstein-Barr virus in type 1 diabetes mellitus. Ann Trop Med Public Heal. 2019; 22(09): 90-99.

13. Mohammed AH, Saber AA. THE possible association between Epstein-barr virus and type 1 diabetes mellitus. Iraqi JMS. 2019;17(3\&4):175-82. 
14. Shah V, Wu M, Polsky S, Snell-Bergeon J, Sherr J, Cengiz E, et al. Gender differences in diabetes self-care in adults with type 1 diabetes: Findings from the T1D Exchange clinic registry. J Diabetes Complications. 2018 Aug 1;32(10): 961-965.

15. Zayed H. Genetic Epidemiology of Type 1 Diabetes in the 22 Arab Countries. Curr Diab Rep. 2016;16(5): 37.

16. Almahfoodh D, Alabbood M, Alali A, Mansour A. Epidemiology of Type 1 diabetes mellitus in Basrah, Southern Iraq: a retrospective study. Diabetes Res Clin Pract. 2017;133: 104-108.

17. Atkinson MA, Eisenbarth GS, Michels AW. Type 1 diabetes. Lancet. 2014;383(9911):69-82.

18. Särnblad S, Berg L, I D, Jönsson Å, Forsander G. Diabetes management in Swedish schools: A national survey of attitudes of parents, children, and diabetes teams. Pediatr Diabetes. 2014;15(8): 550-556.

19. Bixo A, Akesson K, Ilvered R, Forsander G, Särnblad S. Self-care management of type 1 diabetes has improved in Swedish schools according to children and adolescents. Acta Paediatr. 2017;106(12): 1987-1993.

20. Patterson C, Gyürüs E, Rosenbauer J, Cinek O, Neu A, Schober E, et al. Trends in childhood type 1 diabetes incidence in Europe during 1989-2008: Evidence of non-uniformity over time in rates of increase. Diabetologia. 2012; 55(8): 2142-2147.

21. Bendas A, Rothe U, Kiess W, Kapellen T, Stange T, Manuwald U, et al. Trends in Incidence Rates during 1999-2008 and Prevalence in 2008 of Childhood Type 1 Diabetes Mellitus in GERMANY Model-Based National Estimates. PLoS One. 2015; 10(7): e0132716.

22. Vehik K, Ajami NJ, Hadley D, Petrosino J, Burkhardt B. The Changing Landscape of Type 1 Diabetes: Recent Developments and Future Frontiers. Curr Diab Rep. 2013;13(5): 642-650.

23. Piffaretti C, Mandereau-Bruno L, Guilmin-Crépon S, Choleau C, Coutant R, Fosse-Edorh S. Trends in childhood type 1 diabetes incidence in France, 2010 - 2015. Diabetes Res Clin Pract. 2018;149: 200-207.

24. World Health Organization. Laboratory diagnosis and monitoring of diabetes mellitus. World Health Organization, 2003.

25. Suliman H. The relation of age to the severity of Type I diabetes in children. J Family Community Med. 2010;17(2): 87-90.

26. Ramanathan K, Karthick H, Arun N. Structure Based Drug Designing for Diabetes Mellitus. J Proteomics Bioinforma. 2010;3(11):310-313.

27. von Poblotzki A, Gerdes C, Reischl U, Wolf H, Modrow S. Lymphoproliferative responses after infection with human parvovirus B19. J Virol. 1996;70(10):7327-7330.

28. Munakata Y, Kodera T, Saito T, Sasaki T. Rheumatoid arthritis, type 1 diabetes, and Graves' disease after acute parvovirus B19 infection. Lancet. 2005;366(9487):780. 